\title{
Agriculture biologization levels in cultivation of spring barley in forest steppe of middle Volga
}

\author{
Natalia P. Bakaeva*, Olga L. Saltykova, and Maksim S. Prikazchikov \\ Samara State Agrarian University, 446442, Kinel, Samara region, Russia
}

\begin{abstract}
The paper considers different levels of biologization in agriculture as provided by crop rotation with different fallow types with placement of fertilizers at a level of $40 \mathrm{t} / \mathrm{ha}$, basic soil treatment, leaving straw in the field for all crops of five-field crop rotation and application of mineral fertilizers. High barley yields were obtained through the years of the study. Correlation analysis revealed a direct dependence between total biogenesity of soil and grain yield, which is fully actualized depending on meteorological conditions, varietydependent peculiarities of Povolzhsky 85 barley and agricultural processes applied aimed at increasing biologization of agriculture and protecting soil fertility.
\end{abstract}

\section{Introduction}

Spring barley is one of the most important basic crops, as it is involved in food production, fodder production and brewery; the crop covers relatively large acreage in the grain balance of Russia and the world alike. Spring barley was cultivated as the last crop of the five-course rotation. The rotation facilitates replenishment and better use of soil nutrients and fertilizers, improves and supports advantageous physical and biological soil conditions, prevents infestation of crops with weeds, diseases and pests, reduces pesticide load onto soil and plants, facilitates production of high-quality agricultural products [1].

In barley cultivation technologies, soil treatment is the most important agricultural practice, facilitating creation of advantageous phytosanitary conditions in the soil and determining high yields [2].

Barley requires large amounts of easily available nutrients in the soil during its first period of growth and development. Among the macroelements, barley demands mostly nitrogen, especially during the period starting from tillering to stem elongation. Organic fertilizers are mostly placed under forecrop, as barley is more efficient in using the aftermath of the organic fertilizers introduced, when the nutrients are already in a plant-accessible form.

The final indicator in assessment of various basic soil treatment systems is yield and its class, reflecting effect of all the culture conditions managed with climatic features, as well as modifiable agrotechnical conditions [3]. Simultaneously, a number of researchers note reduced yield of barley when the basic soil treatment is minimized [3-5]. Thus, lack of consistency in opinions on methods, procedures and systems of soil treatment in the context of their influence over yield of spring barley justify additional research in this area.

Preservation and improvement of soil fertility is as important as high and stable yield of crops; these objectives are provided by biologization of agriculture. Determining a relation between yield and biological indicators of soil fertility is highly relevant.

Different levels of biologization of agriculture are considered, including crop rotations with various fallow types, with placement of organic fertilizers in the amount of $40 \mathrm{t} / \mathrm{ha}$, basic soil treatment, with minimal soil treatment, leaving straw in the field after all the crops in the five-course rotation (one tonne of straw is equivalent to 3.5 tonnes of manure as per dry organic matter), application of mineral fertilizers.

Grain yield is a generalizing indicator that allows assessing effectiveness of various elements involved in biologization of agricultural system. It also allows revealing links between yields of spring barley and biological indicators of soil fertility, that is, correlation coefficients between yield and general biogenesity of the soil.

\section{Materials and methods}

\subsection{Subjects of research}

The research was undertaken at experimental fields of the Department of Agriculture, Soil Science, Agrochemistry and Land Registers of Samara State Agricultural University in 2005-2008. Yield was determined for spring barley, variety Povolzhsky 65 for differing meteorological conditions of 2005-2008. According to the nearby Ust-Kinelskaya meteorological station, the following vegetation conditions of agricultural periods were observed. The year of 2005 was generally beneficial, with a summer dry period. The thermal regime was higher than normal with a short cool period and deficit of precipitation. Hydrothermal coefficient for the period of

Corresponding author: bakaevanp@mail.ru 
May-September was 0.55 , corresponding to very dry conditions. The year of 2006 was characterized by increased temperatures and abundant rains. Conditions of the vegetation period were quite beneficial for growth and development. Precipitation in July and August did not cause loss of yield. Hydrothermal coefficient for the period of May-September was 1.08, corresponding to mildly dry conditions. In 2007 , the thermal regime was unstable, with abundant rains, atmospheric drought in late July and August, which prevented achieving high results, in both quality and quantity of grain. Hydrothermal coefficient for the period of May-September was 1.02, corresponding to mildly dry conditions. The year of 2008 was characterized by increased thermal regime and very low amount of precipitation. The hydrothermal coefficient for the period of May-September was 0.89, which is close to longtime average of 0.83 .

The crops were planted in two rotations with the following order of crops: first rotation - 1. complete fallow; 2. winter wheat; 3 . soy; 4. spring wheat; 5. barley; second rotation -1 . green-manured fallow (mustard); 2 . winter wheat; 3 . soy; 4. spring wheat; 5 . barley. Organic fertilizers were placed into fallows $-40 \mathrm{t} / \mathrm{ha}$ of manure. The subject of the study was the last crop of the rotation, barley of Povolzhsky 65 variety. The experiment was conducted in triple replication, the area of a single experimental plot was $780 \mathrm{~m}^{2}$. The soil in the area is a typical mid-humus chernozem of medium thickness with heavy clay loam. This soil has a $\mathrm{pH}$ value close to neutral, a medium humus content and a relatively high absorption capacity. By its physical, chemical and water-related properties, this soil meets the requirements posed for successful planting of leading field crops [6]

Three different systems of basic soil treatment were studied in the rotations. Combined - called hereinafter plowed or plowing for the sake of brevity- is a common soil treatment technology for the central zone of the Samara oblast. The soil treatment consisted of scuffing to $6-8 \mathrm{~cm}$ and plowing to $20-22 \mathrm{~cm}$ for spring grains, to $25-27 \mathrm{~cm}$ for complete fallow, as well as a surface treatment to $6-8 \mathrm{~cm}$ before sowing winter wheat.

Nonmoldboard cultivation (hereinafter loosening consisted in autumn mechanical loosening of the soil to a depth of $6-8 \mathrm{~cm}$ with a repetition to $1-12 \mathrm{~cm}$ for spring grains; nonmoldboard cultivation to 28-30 $\mathrm{cm}$ was used before complete fallow. No autumn mechanical treatment, meaning there was not soil treatment in the autumn, while after harvesting a forecrop, Tornado herbicide was applied in a dosage of $31 /$ ha. In the spring, the crop was sown by the direct seeding method. Grain straw was chaffed during the harvesting and left in the field in all the variants of the experiment. Additionally, calculated doses of mineral fertilizers were placed under all the crops.

When cultivating barley, the basic soil treatment variant applied the stated variants of fertilizers; row crops received a mineral fertilizer with a composition of N25ם25u25.

During the tillering of spring wheat and spring barley, Prima herbicide was used in all the variants of the experiment in a dosage of $500 \mathrm{mk} / \mathrm{ha}$ to subdue annual dicotyledonous weeds. Sowing of spring barley in the experiments was performed in region-specific optimal periods, in the transverse direction to the basic soil treatment, using a DMC Primera seeding machine. Harvesting was performed with a TERRION selection combine harvester in the firm ripe stage. Before harvesting, sheaves were collected from $0.25 \mathrm{~m}^{2}$ plots. The material from the sheaves served to determine the structure and quality of the harvest.

\subsection{Research methods}

The following observations and studies were made: 1 . Soil moisture content were determined by the thermostatand-weight methods in two periods, before the sowing and before the harvesting spring barley at a depth of $1 \mathrm{~m}$ every $10 \mathrm{~cm}$ in triple repetition. 2. Bulk density of the soil was determined by the cylinder method; soil samples were taken for all the studied variants every $10 \mathrm{~cm}$ to a depth of $30 \mathrm{~cm}$ in triple repetition, before the sowing and before the harvesting of crops. 3. Harvest accounting was performed by continuous harvesting of the accounting area with a combine harvester. The harvest was then brought to $100 \%$ purity and $14 \%$ moisture content [6]. 4 . Accounting of structural elements of the harvest was performed according to the method of the State Commission for Variety Testing. 5. Mathematical processing of data was performed in Microsoft Excel and Statistical package.

\section{Research Results}

Yield of spring barley var. Povolzhsky 65 was being determined through 2005-2008; the experimental design and results are shown in Table 1.

Yield values of the spring barley var. Povolzhsky 65 depending on soil treatment methods, fallow type and fertilizers as obtained in 2005-2008 are shown in Table 1.

Under the observed weather conditions, the highest yield of spring barley var. Povolzhsky 65 was obtained in 2006. Fertilizing also facilitated increased yield. 
As for soil treatment, the variant with plowing showed the highest results, for both complete fallow and greenmanured fallow. This is due to the fact that during the plowing, the plant residues, including those of greenmanure crop, are placed into deeper soil layers and mineralize slower, than in the case of loosening or without autumn mechanical treatment. As a result, they have positive impact on the crop for a longer period.

Yield indicator in the variants of loosening and no autumn mechanical treatment were close, at 1.26...1.24 $\mathrm{t} / \mathrm{ha}$ in rotation with complete fallow and $1.45 \ldots 1.44 \mathrm{t} / \mathrm{ha}$ in rotation with green-manured fallow. Fertilized background facilitated a $7 \%$ increase in yield. 
Table 1. Yield values of the spring barley var. Povolzhsky 65 depending on soil treatment methods, fallow type and fertilizers through the research period

\begin{tabular}{|c|c|c|c|c|c|c|c|}
\hline \multicolumn{3}{|c|}{ Variants } & \multicolumn{5}{|c|}{ Yield, t/ha } \\
\hline $\begin{array}{l}\text { Fallow type } \\
\text { (factor A) }\end{array}$ & $\begin{array}{l}\text { Soil treatment } \\
\quad(\text { factor B })\end{array}$ & $\begin{array}{l}\text { Fertilizer } \\
\text { (factor C) }\end{array}$ & 2005 & 2006 & 2007 & 2008 & Average \\
\hline \multirow{6}{*}{ 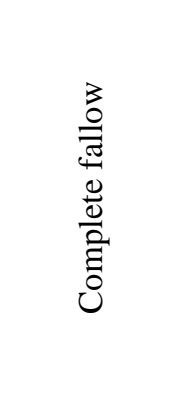 } & \multirow[b]{2}{*}{ Plowing } & No fertilizer & 1.37 & 2.4 & 2.04 & 2.58 & 2.18 \\
\hline & & $\begin{array}{c}\text { Fertilized } \\
\text { background }\end{array}$ & 1.49 & 3.00 & 2.25 & - & 2.25 \\
\hline & \multirow[b]{2}{*}{ Loosening } & No fertilizer & 1.26 & 2.52 & 1.50 & 2.48 & 1.94 \\
\hline & & $\begin{array}{c}\text { Fertilized } \\
\text { background }\end{array}$ & 1.36 & 2.86 & 1.92 & - & 2.05 \\
\hline & \multirow{2}{*}{$\begin{array}{c}\text { No autumn } \\
\text { mechanical } \\
\text { treatment }\end{array}$} & No fertilizer & 1.24 & 2.50 & 1.47 & 2.39 & 1.90 \\
\hline & & $\begin{array}{c}\text { Fertilized } \\
\text { background }\end{array}$ & 1.32 & 2.80 & 1.87 & - & 2.00 \\
\hline \multirow{2}{*}{\multicolumn{2}{|c|}{ Average for complete fallow }} & No fertilizer & 1.29 & 2.59 & 1.67 & 2.48 & 2.01 \\
\hline & & $\begin{array}{c}\text { Fertilized } \\
\text { background }\end{array}$ & 1.39 & 2.89 & 2.01 & - & 2.10 \\
\hline \multirow{6}{*}{ 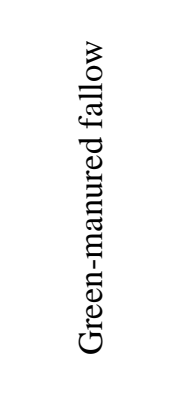 } & \multirow[b]{2}{*}{ Plowing } & No fertilizer & 1.59 & 2.99 & 2.30 & 2.79 & 2.42 \\
\hline & & $\begin{array}{c}\text { Fertilized } \\
\text { background }\end{array}$ & 1.69 & 3.23 & 2.46 & - & 2.46 \\
\hline & \multirow[b]{2}{*}{ Loosening } & No fertilizer & 1.45 & 2.83 & 2.15 & 2.64 & 2.27 \\
\hline & & $\begin{array}{c}\text { Fertilized } \\
\text { background }\end{array}$ & 1.60 & 2.98 & 2.32 & - & 2.30 \\
\hline & \multirow{2}{*}{$\begin{array}{c}\text { No autumn } \\
\text { mechanical } \\
\text { treatment }\end{array}$} & No fertilizer & 1.44 & 2.82 & 2.02 & 2.33 & 2.15 \\
\hline & & $\begin{array}{c}\text { Fertilized } \\
\text { background }\end{array}$ & 1.55 & 2.93 & 2.18 & - & 2.22 \\
\hline \multirow{2}{*}{\multicolumn{2}{|c|}{$\begin{array}{l}\text { Average for green-manured } \\
\text { fallow }\end{array}$}} & No fertilizer & 1.49 & 2.88 & 2.16 & 2.59 & 2.28 \\
\hline & & $\begin{array}{c}\text { Fertilized } \\
\text { background }\end{array}$ & 1.61 & 3.05 & 2.32 & - & 2.33 \\
\hline \multirow{4}{*}{\multicolumn{3}{|c|}{$\begin{array}{l}\text { LSD }_{05} \text { total } \\
\mathrm{LSD}_{05} \text { of factor A } \\
\mathrm{LSD}_{05} \text { of factor B } \\
\text { LSD }_{05} \text { of factor C }\end{array}$}} & 0.07 & 0.13 & 0.36 & 0.36 & \\
\hline & & & 0.04 & 0.08 & 0.21 & 0.21 & \\
\hline & & & 0.05 & 0.10 & 0.25 & 0.25 & \\
\hline & & & 0.05 & 0.09 & 0.18 & 0.27 & \\
\hline \multicolumn{8}{|c|}{ Average for soil treatments } \\
\hline \multirow{2}{*}{\multicolumn{2}{|c|}{ Average for plowing }} & No fertilizer & 1.48 & 2.87 & 2.17 & 2.67 & 2.30 \\
\hline & & $\begin{array}{c}\text { Fertilized } \\
\text { background }\end{array}$ & 1.59 & 3.12 & 2.36 & - & 2.36 \\
\hline \multirow{2}{*}{\multicolumn{2}{|c|}{ Average for loosening }} & No fertilizer & 1.36 & 2.68 & 1.83 & 2.56 & 2.11 \\
\hline & & $\begin{array}{c}\text { Fertilized } \\
\text { background }\end{array}$ & 1.48 & 2.92 & 2.12 & - & 2.18 \\
\hline \multirow{2}{*}{\multicolumn{2}{|c|}{$\begin{array}{l}\text { Average for No autumn } \\
\text { mechanical treatment }\end{array}$}} & No fertilizer & 1.34 & 2.66 & 1.75 & 2.36 & 2.03 \\
\hline & & $\begin{array}{c}\text { Fertilized } \\
\text { background }\end{array}$ & 1.44 & 2.87 & 2.03 & - & 2.11 \\
\hline
\end{tabular}

In 2006, average yield of barley increased by a factor of 2 in all the variants and amounted to $2.59 \mathrm{t} / \mathrm{ha}$ in rotation with complete fallow, and to 2.88 t/ha in rotation with green-manured fallow, in comparison with 2005. Maximum harvest was obtained in the plowed variant of both rotations. In general, green-manured fallow facilitated a $10 \%$ increase in yield. Fertilized background (mineral fertilizer) facilitated a $10 \%$ increase in the complete fallow variant and a $6 \%$ increase in the greenmanured variant. In the variant with no autumn mechanical treatment and in the loosening variant, the grain yield of spring barley was similar.

In 2007, due to observed weather conditions, there was a decrease in yield, by $35.5 \%$ in the rotation with complete fallow and by $25 \%$ in the rotation with greenmanured fallow. The largest harvests were obtained in

*Corresponding author: bakaevanp@mail.ru 
plowed variants. Advantage of plowing in comparison with loosening and no autumn mechanical treatment amounted to $27 \%$ in the complete fallow rotation. In the rotation with green-manured fallow, the advantage of plowing over other soil treatment methods was lower and reached only $10 \%$. The fertilized background facilitated increasing the yield from 1.67 to $2.01 \mathrm{t} / \mathrm{ha}$ in rotation with complete fallow and from 2.16 to $2.32 \mathrm{t} / \mathrm{ha}$ in the rotation with green-manured fallow through all the variants of the experiment.

In 2008, yields increased from 1.67 to $2.48 \mathrm{t} / \mathrm{ha}$ in the complete fallow rotation, which is $32 \%$ higher. In the rotation with green-manured fallow, the increase amounted to just $16 \%$ in comparison with 2007. Advantage of the complete fallow over the greenmanured fallow amounted to $4 \%$. The largest harvest was recorded for the plowed variant; it amounted to $2.58 \mathrm{t} / \mathrm{ha}$ in the rotation with complete fallow and to $2.79 \mathrm{t} / \mathrm{ha}$ in the rotation with green-manured fallow.

Represented levels of biologization of agriculture: rotations with complete and green-manured fallow (mustard), with placement of organic fertilizer in the equivalent of $40 \mathrm{t} / \mathrm{ha}$ of manure, application of minimal tillering by loosening to $6-8 \mathrm{~cm}$ and without autumn soil treatment, leaving the straw in the fields of all the crops in the five-course rotation and application of calculated doses of mineral fertilizers under each crop for planned yield and grain yield of spring barley.

Indicators of the levels taken from a paper by Markovskaya [7] were used in correlation analysis of yield and its possible relations with biological activity of the soil. General biogenesity of the soil was studied on micromycetes, bacteria and actinomycetes. Through the vegetation, the amount of micromycetes under the plots of spring barley increases in the variants with loosening and without autumn mechanical treatment in comparison with the plowed variants. It is provided by decreased anthropogenic load on the soil.

Maximum bacteria count was registered for plowing, leading to reinforcement of humus mineralization in this variant. Less actinomycetes were recorded for the rotation with green-manured fallow, which provides higher preservation of humus [8].

Thus, fluctuations in the microorganism count increase the biologization of agriculture and facilitate it in cultivation of spring barley. Thus, correlation analysis of obtained grain yield values of spring barley for various variants considered in research through the years with the general biogenesity of the soil under plantings of the crop becomes important. The results of the correlation analysis are shown in Table 2.

Correlation coefficients for yield indicators and general biogenesity show that the degree of dependence between the studied characteristics, namely, yield of spring barley var. Povolzhsky 65 and general biogenesity of the soil under the plantings is average or strong, with direct correlation. The shown linear regression equations describe the existing dependence quite well [9].

Direct correlation through all the variants of the experiment is a correlation where an increase in one variable correlates to an increase in another one. For instance, when yield increases, general biogenesity of the soil increases as well. That is, the correlation analysis revealed a direct dependence between the studied characteristics - total biogenesity of the soil created by the total of microorganism in the soil - and grain yield, which is fully actualized depending on meteorological conditions, variety-dependent peculiarities of Povolzhsky 85 barley and agricultural processes applied aimed at increasing biologization of agriculture and protecting soil fertility.

Table 2. Correlation coefficients and degree of dependence for yield indicators and general biogenesity of the soil

\begin{tabular}{|c|c|c|c|c|}
\hline \multicolumn{2}{|c|}{ Traits } & $\begin{array}{c}\text { Correlation } \\
\text { coefficient }\end{array}$ & $\begin{array}{c}\text { Degree of } \\
\text { dependence }\end{array}$ & $\begin{array}{c}\text { Regression } \\
\text { equation }\end{array}$ \\
\hline \multicolumn{5}{|c|}{ In rotation with complete fallow } \\
\hline \multirow{7}{*}{ 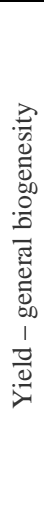 } & Plowing & $r=0.62$ & $\begin{array}{c}\text { medium } \\
\text { direct }\end{array}$ & $\begin{array}{c}\mathrm{y}=3.96 \mathrm{x}- \\
1.39\end{array}$ \\
\hline & Loosening & $r=0.65$ & $\begin{array}{l}\text { strong } \\
\text { direct }\end{array}$ & $\begin{aligned} \mathrm{y}= & 3.34 \mathrm{x}+ \\
& 1.34\end{aligned}$ \\
\hline & $\begin{array}{c}\text { No autumn } \\
\text { mechanical } \\
\text { treatment }\end{array}$ & $\mathrm{r}=0.79$ & $\begin{array}{l}\text { strong } \\
\text { direct }\end{array}$ & $\begin{array}{c}y=4.78 x- \\
1.61\end{array}$ \\
\hline & \multicolumn{4}{|c|}{ In rotation with green-manured fallow } \\
\hline & Plowing & $\mathrm{r}=0.59$ & $\begin{array}{c}\text { medium } \\
\text { direct }\end{array}$ & $\begin{array}{c}\mathrm{y}=6.28 \mathrm{x}- \\
5.74\end{array}$ \\
\hline & Loosening & $\mathrm{r}=0.79$ & $\begin{array}{l}\text { strong } \\
\text { direct }\end{array}$ & $\begin{array}{c}y=6.36 x- \\
6.29\end{array}$ \\
\hline & $\begin{array}{c}\text { No autumn } \\
\text { mechanical } \\
\text { treatment }\end{array}$ & $\mathrm{r}=0.78$ & $\begin{array}{l}\text { strong } \\
\text { direct }\end{array}$ & $\begin{array}{c}y=7.78 x- \\
7.49\end{array}$ \\
\hline
\end{tabular}

\section{Discussion}

Through the years of the research (2005-2008), a small advantage of the green-manured fallow over the complete fallow was noted, amounting to $11.8 \%$. Let us note that the plowed variant was characterized with the largest yield values for both rotations studied. The variants with loosening and without autumn mechanical treatment were generally very similar: 1.94 and $1.90 \mathrm{t} / \mathrm{ha}$, respectively in the rotation with complete fallow and 2.27 and $2.15 \mathrm{t} / \mathrm{ha}$ in the rotation with green-manured fallow against the nonfertilized background.

Fertilized background provides an advantage of $4.3 \%$ over the complete fallow in the rotation with complete fallow and that of $2.1 \%$ in the rotation with greenmanured fallow. The shown linear regression equations describe the existing dependence between the yield and general biogenesity of the soil quite well.

Direct correlation through all the variants of the experiment is a correlation where an increase in one variable correlates to an increase in another one. For instance, when yield increases, general biogenesity of the soil increases as well.

\section{Conclusion}

On average, the yield of spring barley var. Povolzhsky 65 was high for all the soil treatment and fallow variants in 2005-2008. Varying meteorological conditions allowed for rather high yields. On average, the yield was in the 
range of 1.3...3.20 t/ha. The highest values were obtained in 2006. They amounted to $3.23 \mathrm{t} / \mathrm{ha}$ for the plowed variant with green-manured fallow against the fertilized background; the values were somewhat lower for complete fallow against the fertilized background at 3.0 t/ha.

On average, the plowed variant provided high grain yield; loosening reduced the yield by $8.3 \%$; no autumn mechanical treatment led to a reduction by $11.7 \%$. On average, fertilization increased the yield by $2.6 \%$ in the plowed variants, by $3.2 \%$ in the loosening variants and by $3.8 \%$ in the variants without autumn mechanical treatment.

Correlation analysis revealed a direct dependence between the studied characteristics - total biogenesity of the soil created by the total of microorganism in the soil and grain yield, which is fully actualized depending on meteorological conditions, variety-dependent peculiarities of Povolzhsky 85 barley and agricultural processes applied aimed at increasing biologization of agriculture and protecting soil fertility.

\section{References}

1. N.P. Bakaeva, Productivity and Quality of Harvest of Field Crops, 161-165 (Samara, 1999)

2. N.K. Shikula, Soil-protecting System of Agriculture (Prapor, Kharkov, 1987)

3. S.V. Barsukova, Current Issues in Agronomical Science in the 21st Century, 309-315 (Samara, 2004)

4. A.Ya. Bagautdinov, Annals of the Bashkir State Agricultural University, 4, 19-21 (2011)

5. L.N. Vislobokova, Grain Farming in Russia, 1, 77-89, (2012)

6. S.N. Zudilin, Vavilov Readings, 455-460 (2017)

7. G.K. Markovskaya, Current Issues in Agronomical Science in the 21 st Century, 386-392 (Samara, 2004)

8. O.A. Chugunova, Annals of Samara State Agricultural Academy, 4, 22-27 (2018)

9. N P Bakaeva, IOP Conference Serues: Earth and Environmental Science, 315, $022056 \quad$ (2019) doi:10.1088/1755-1315/315/2/02205 